Vol. 14 (2005): 311-324.

\title{
Effects of some organic acids and salts on microbial fermentation in the digestive tract of piglets estimated using an in vitro gas production technique
}

\author{
Kirsi Partanen \\ MTT Agrifood Research Finland, Animal Production Research, Swine Research, Tervamäentie 179, \\ FI-05840 Hyvinkää, Finland, e-mail: kirsi.partanen@mtt.fi \\ Taina Jalava \\ MTT Agrifood Research Finland, Animal Production Research, Animal Nutrition, \\ FI-31600 Jokioinen, Finland
}

\begin{abstract}
An in vitro gas production technique was used to screen different organic acids (formic, propionic, lactic, citric, and fumaric acid), organic salts (calcium formate, potassium sorbate, and sodium benzoate), and inorganic phosphoric acid for their ability to modulate microbial fermentation in the digestive tract of piglets. For the incubation, $40 \mathrm{ml}$ of culture medium (53\% buffer, $45 \%$ frozen ileal digesta, and $2 \%$ fresh faeces) was dispensed in vessels containing $5 \mathrm{ml}$ of buffer, $0.5 \mathrm{~g}$ of feed, and $20 \mu \mathrm{l}$ of liquid or $20 \mathrm{mg}$ of solid acidifiers. Gas production was measured every 15 min during the $24 \mathrm{~h}$ incubation at $39^{\circ} \mathrm{C}$, and a Gompertz bacterial growth model was applied to the gas production data. Formic acid was the only acid that reduced the maximum rate of gas production $\left(\mu_{\mathrm{m}}\right)$ compared to that in the control treatment $(\mathrm{P}<0.05)$. The $\mu_{\mathrm{m}}$ was slower in vessels with formic acid than in those with calcium formate, citric acid, and potassium sorbate $(\mathrm{P}<0.05)$. Calcium formate increased the $\mu \mathrm{m}$ compared to the control treatment $(\mathrm{P}<0.05)$. The maximum volume of gas produced and the lag time did not differ between different acidifiers $(\mathrm{P}>0.05)$. When investigating formic-acid-based mixtures that contained $1-5 \%$ of potassium sorbate and/or sodium benzoate, the estimated parameters for the Gompertz growth model did not differ from those for treatments with plain formic acid $(\mathrm{P}>0.05)$. However, concentrations of total volatile fatty acids, acetic acid, propionic acid, and $\mathrm{n}$-butyric acid were reduced by all the mixtures $(\mathrm{P}<0.05)$, but not by plain formic acid $(\mathrm{P}>0.05)$. In conclusion, organic acids and salts were found to differ in their ability to modulate microbial fermentation in the digestive tract of piglets. Mixing formic acid with potassium sorbate or sodium benzoate changed fermentation patterns, and the possibility to use them to enhance the antimicrobial effect of formic acid should be investigated further in vivo.
\end{abstract}

Key words: pigs, fermentation, organic acids, organic salts 


\section{Introduction}

In recent years, interest in the use of organic acids and their salts as alternatives to antibiotic growth promoters has increased dramatically. The addition of organic acids to swine diets has been shown to enhance growth and the feed to gain ratio of weaned piglets and fattening pigs (Kirchgessner and Roth 1988, Partanen and Mroz 1999). Although the exact mechanisms of the growth-promoting effect of organic acids are not known, it seems that their growthpromoting effects are primarily due to their effects on gastrointestinal microflora. Organic acids appear to modulate microbial activity and fermentation in the gastrointestinal tract of pigs (Jensen 1998). Changes in microbial counts (Maribo et al. 2000a, b, Canibe et al. 2001) and microbial metabolite concentrations (ammonia, lactic acid, and volatile fatty acids) have been found primarily in the stomach and small intestinal contents of pigs fed diets supplemented with organic acids (Roth et al. 1992, Canibe et al. 2001, Partanen et al. 2001a). The changes in microbial fermentation could result in nutrients being diverted from microbes to the animal (Jensen 1998), as well as improved apparent digestibility of nutrients, particularly that of protein and fat (Partanen et al. 2001a). Because of the high costs of animal experiments, an in vitro method could be a useful tool to screen different organic acids for their effects on microbial fermentation in the digestive tract of pig. The cumulative gas production technique has been successfully used to evaluate the effects of organic acids on caecal fermentation in pigs (Piva et al. 1999, 2002). Our aim was to use the in vitro gas production technique to study to what extent different organic acids, organic salts, and acid mixtures can modulate microbial fermentation in the digestive tract of piglets. The fermentation medium contained ileal digesta and feed as the substrate and faeces from young piglets as the inoculum.

\section{Material and methods}

The experimental protocol was reviewed and approved by the MTT Animal Care and Use Committee.

\section{Animals, diets, and the collection of digesta and faeces}

Ileal digesta was collected from a cannulated, growing pig (Finnish Landrace) when its body weight was between 50 and $80 \mathrm{~kg}$. When its body weight had been $39 \mathrm{~kg}$, this pig had been fitted with a PVC cannula at the caecum according to the post-valve T-cannulae technique (van Leeuwen et al. 1991). Premedication and anaesthesia were carried out, and the pig was housed as described by Partanen et al. (2001b). The pig had two weeks time to recover from the surgery before it was fed a grower diet based on barley, wheat bran, and soya bean meal (Table 1). The pig was fed twice a day (0600 and 1800) and it was given $100 \mathrm{~g}$ of feed per $\mathrm{kg}$ of metabolic body weight $\left(\mathrm{BW}^{0.75}\right)$ per day. Water was available ad libitum. Ileal digesta was collected 3-4 $\mathrm{h}$ after the morning meal by attaching a plastic bag with a rubber band to the barrel of the opened cannulae. The bag was removed immediately when a digesta pulse entered the bag. The bag was emptied under constant $\mathrm{CO}_{2}$ flow into a bottle that was frozen within 30 min after the initiation of the digesta collection. Because freezing stops microbial activity in digesta, faeces from piglets were used as inoculum. Faeces were collected from 2-4-week-old suckling piglets from six litters (Finnish Landrace) that had free access to creep feed containing no antimicrobials (Table 1). Faeces were collected in the morning and transported to the laboratory in anaerobic bags (BBL ${ }^{\circledR}$ GasPak Pouch ${ }^{\text {TM }}$ System, Becton Dickinson Microbiology Systems, USA) within $2 \mathrm{~h}$ of collection.

\section{In vitro fermentation}

We used an automatic batch fermentation system that consisted of a thermostatically controlled water bath, magnetic stirrers (Variomag Telesystem HP 15 P, H + P Labortechnik AG, Munich, Germany), solenoid valves (121M13 fitted with coil 488980), pressure transducers (142PC05D, Honeywell, Inc., Minneapolis, USA), and a modular 
Vol. 14 (2005): 311-324.

Table 1. Ingredients and calculated composition of diets fed to pigs from which ileal digesta and faecal inoculum were collected for in vitro fermentation.

\begin{tabular}{|c|c|c|}
\hline & $\begin{array}{c}\text { Diet of pig from which ileal } \\
\text { digesta was collected }\end{array}$ & $\begin{array}{l}\text { Diet of piglets from which faeca } \\
\text { inoculum was collected }\end{array}$ \\
\hline \multicolumn{3}{|l|}{ Ingredients, $\mathrm{g}$ per $\mathrm{kg}$ of feed } \\
\hline Barley & 653.3 & 378.6 \\
\hline Wheat & & 400.0 \\
\hline Wheat bran & 150.0 & - \\
\hline Oat meal & - & - \\
\hline Soya bean meal & 153.5 & 106.1 \\
\hline Low lactose whey powder (lactose $380 \mathrm{~g} \mathrm{~kg}^{-1}$ ) & - & 30.0 \\
\hline Fish meal & - & 60.0 \\
\hline Rapeseed oil & 18.9 & - \\
\hline Limestone & 8.1 & 9.7 \\
\hline Monocalcium phosphate & 2.6 & 1.6 \\
\hline L-Lysine $\mathrm{HCl}$ & 0.6 & 1.7 \\
\hline Mineral and vitamin premix ${ }^{1}$ & 13.0 & 12.4 \\
\hline \multicolumn{3}{|l|}{ Calculated composition } \\
\hline Net energy, $\mathrm{MJ} \mathrm{kg}^{-1}$ & 9.1 & 9.2 \\
\hline Crude protein, $\mathrm{g} \mathrm{kg}^{-1}$ & 160 & 186 \\
\hline Apparent ileal digestible lysine, $\mathrm{g} \mathrm{kg}^{-1}$ & 6.9 & 9.3 \\
\hline Apparent ileal digestible threonine, $\mathrm{g} \mathrm{kg}^{-1}$ & 4.2 & 5.6 \\
\hline Apparent ileal digestible methionine+cystine, $\mathrm{g} \mathrm{kg}^{-1}$ & 4.2 & 5.6 \\
\hline Calcium, $\mathrm{g} \mathrm{kg}^{-1}$ & 6.9 & 9.0 \\
\hline Phosphorus, $\mathrm{g} \mathrm{kg}^{-1}$ & 6.2 & 5.5 \\
\hline
\end{tabular}

${ }^{1}$ Ten grams of premix contained the following minerals and vitamins: $1.8 \mathrm{~g} \mathrm{Ca}, 0.6 \mathrm{~g} \mathrm{P}, 0.4 \mathrm{~g} \mathrm{Mg}, 2.5 \mathrm{~g} \mathrm{NaCl}, 79 \mathrm{mg} \mathrm{Fe}$, $17 \mathrm{mg} \mathrm{Cu}, 70 \mathrm{mg} \mathrm{Zn,} 18 \mathrm{mg} \mathrm{Mn}, 0.21 \mathrm{mg} \mathrm{Se,} 0.17 \mathrm{mg} \mathrm{I}, 3980 \mathrm{IU}$ vitamin A, 398 IU vitamin $\mathrm{D}_{3}, 38 \mathrm{mg}$ vitamin E, 1.5 $\mathrm{mg}$ thiamin, $3.6 \mathrm{mg}$ riboflavin, $2.1 \mathrm{mg}$ pyridoxine, $15 \mu \mathrm{g}$ vitamin $\mathrm{B}_{12}, 0.15 \mathrm{mg}$ biotin, $11 \mathrm{mg}$ pantothenic acid, $15 \mathrm{mg}$ niacin, $1.5 \mathrm{mg}$ folic acid, and $1.5 \mathrm{mg}$ vitamin $\mathrm{K}$.

programmable logic controller (MELSEC AnS, made by Mitsubishi Electric Europe $\mathrm{GmbH}$, Industrial Automation, Ratingen, Germany). The AnS unit was controlled by the FactoryLink program (Beijers, G \& L Beijer Electronics AB; Malmö, Sweden). The system was protected against electric power problems by Powerware Prestige 6000 uninterruptible power supply (Exide Electronics Oy, Espoo, Finland).

The fermentation buffer ( $\mathrm{pH}$ 7.78) was prepared according to Breves et al. (1991): $25 \mathrm{mmol}$ $\mathrm{NaHCO}_{3}, 1.0 \mathrm{mmol} \mathrm{NaH} \mathrm{PO}_{4} \cdot \mathrm{H}_{2} \mathrm{O}, 2.0 \mathrm{mmol}$ $\mathrm{Na}_{2} \mathrm{SO}_{4}, 115 \mathrm{mmol} \mathrm{NaCl}, 10 \mathrm{mmol} \mathrm{KCl}, 2.5 \mathrm{mmol}$ $\mathrm{MgCl}_{2}, 2.5 \mathrm{mmol} \mathrm{CaCl}_{2}$, and $5.0 \mathrm{mmol} \mathrm{NH}_{4} \mathrm{Cl}$ per litre of distilled water. The buffer was warmed to $39^{\circ} \mathrm{C}$ and saturated with $\mathrm{CO}_{2}$ for $2 \mathrm{~h}$ before use. Frozen ileal digesta was thawed and diluted with fermentation buffer 1:2 using a Waring Laboratory
Blender (GWB, USA) for $60 \mathrm{sec}$. Fresh piglet faeces used as inoculum were diluted with buffer 1:5 and mixed with the Waring Laboratory Blender for $60 \mathrm{sec}$. Faeces-buffer and digesta-buffer mixtures were mixed 1:10 so that the final mixture contained $2 \%$ faeces, $45 \%$ ileal digesta, and $53 \%$ buffer. The mixing ratio of digesta and buffer was adopted from the study of Piva et al. (2002). The concentration of faecal inoculum in fermentation fluid was modified based on the study of Knarreborg et al. (2002). The culture medium was sampled to determine the lactic acid, volatile fatty acids (VFA), and ammonia concentrations at time zero.

For the incubation, $40 \mathrm{ml}$ of culture medium was dispensed into a 100-ml vessel that contained a magnetic bar, $0.5 \mathrm{~g}$ of basal diet (ground to pass through a 1-mm sieve) as substrate, $5 \mathrm{ml}$ of buffer, and the investigated acidifier. Initial $\mathrm{pH}$ was meas- 
Partanen, K. \& Jalava, T. Effects of organic acids and salts on swine microbial fermentation

ured, and the vessel was flushed with $\mathrm{CO}_{2}$ before it was sealed with a rubber stopper and connected to an automatic gas production system. The vessels were incubated at $39^{\circ} \mathrm{C}$, and gas production was measured every $15 \mathrm{~min}$ for $24 \mathrm{~h}$. The magnetic stirrer mixed the vessel contents for $20 \mathrm{sec}$ at intervals of $30 \mathrm{sec}$. At the end of the 24-h incubation, the fermentation fluid was sampled to determine its $\mathrm{pH}$ and its microbial metabolite concentrations. The fermentation fluid was frozen as such for lactic acid analysis according to Haacker et al. (1983). Volatile fatty acids were analysed according to Huhtanen et al. (1998), and for the analysis $1 \mathrm{ml}$ of fermentation fluid was first mixed with $0.1 \mathrm{ml}$ of saturated $\mathrm{HgCl}_{2}$, then with $0.4 \mathrm{ml}$ of $1 \mathrm{~N} \mathrm{NaOH}$, and then frozen. For ammonia analysis, which was performed according to McCullough (1967), $1 \mathrm{ml}$ of fermentation fluid was mixed with $20 \mu 1$ of $50 \%$ $\mathrm{H}_{2} \mathrm{SO}_{4}$ and then frozen.

In vitro fermentations were carried out in three consecutive steps. Firstly, the suitable acid addition level for the culture medium was obtained by investigating the effects on the cumulative gas production resulting from adding $0,5,10,20$, or $30 \mu \mathrm{l}$ of formic acid (100\%) to $45 \mathrm{ml}$ of culture medium. The respective formic acid concentrations were 2.9, 5.9, 11.8, and $17.7 \mathrm{mM}$, and there were two vessels for each formic acid level. Secondly, we compared the effects of different organic acids (formic, propionic, lactic, citric, and fumaric acid), organic salts (calcium formate, potassium sorbate, and sodium benzoate), and inorganic phosphoric acid by adding $20 \mu \mathrm{l}$ of liquid or $20 \mathrm{mg}$ of solid acidifiers to $45 \mathrm{ml}$ of fermentation medium. There were at least three vessels per acid or salt. We ended up comparing different acidifiers on a volume/ weight-basis because additions producing a similar molar concentration (12 mM) did not succeed. The molecular weights of the investigated acids and salts vary greatly, from $46 \mathrm{~g} \mathrm{~mol}^{-1}$ for formic acid to $192 \mathrm{~g} \mathrm{~mol}^{-1}$ for citric acid. Compared to the situation with formic acid, the amount in grams of the $12 \mathrm{mM}$ additions of other acids and salts were 1.6-4.2 times higher, and consequently several of the additives completely stopped fermentation in the vessels. Furthermore, dietary organic acids are generally compared in vivo by adding acids to feed on the basis of weight rather than molar concentration. In the third step, we studied the effects of mixing small amounts of sodium benzoate and/or potassium sorbate with formic acid. Both of these organic salts are known to be effective antimicrobials (preservatives) in small dosages if combined with other acids that lower the pH (Chipley 1993, Sofos and Busta 1993). The investigated mixtures contained 50, 150, or $250 \mathrm{mg}$ of sodium benzoate or potassium sorbate or $150 \mathrm{mg}$ of both in $5 \mathrm{ml}$ of formic acid (100\%), resulting in mixtures containing 1,3 , or $5 \%$ sodium benzoate or potassium sorbate or $2.5 \%$ of each. The addition level of these mixtures was $20 \mu \mathrm{l}$ per $45 \mathrm{ml}$ of fermentation medium, and there were three vessels per each acid treatment.

\section{Calculations and statistical analysis}

The proportion of undissociated acid in the fermentation medium at the initial $\mathrm{pH}$ level was calculated according to the Henderson-Hasselbach equation: $\mathrm{pH}=\mathrm{pK}_{\mathrm{a}}+\log \left[\mathrm{A}^{-}\right] /[\mathrm{HA}]$. A Gompertz bacterial growth model (Schofield et al. 1994) was adapted to the gas production data by using the NLIN procedure of SAS (1998). This model assumes that substrate limitations have no effect on growth, that the rate of growth is proportional to cell mass, and that the growth rate decays exponentially with time due to inactivation of the bacteria. An alternative interpretation is that substrate levels limit growth in a logarithmic manner. The equation for gas production is as follows:

$$
\mathrm{V}=\mathrm{V}_{\mathrm{F}} \exp \left\{-\exp \left[1+\left(\mu_{\mathrm{m}} e / \mathrm{V}_{\mathrm{F}}\right)(\lambda-\mathrm{t})\right]\right\}
$$

where, according to Zwietering et al. (1990), V = volume of gas produced at time $\mathrm{t}, \mathrm{t}=$ fermentation time $(\mathrm{h}), \mathrm{V}_{\mathrm{F}}=$ maximum volume of gas produced (ml), $\mu_{\mathrm{m}}=$ maximum rate of gas production $(\mathrm{ml}$ $\mathrm{h}^{-1}$ ), which occurs at the point of inflection of the gas curve, and $\lambda=$ the lag time (h), as the time axis intercept of a tangent line at the point of inflection. The duration of the exponential phase was calculated from the parameters of the Gompertz function as follows (Zwietering et al. 1992): 
Vol. 14 (2005): 311-324.

Exponential phase $(\mathrm{h})=$

$$
\mathrm{V}_{\mathrm{F}} /\left(\mu_{\mathrm{m}} e\right)\{1-\ln [(3-\sqrt{5}) / 2]\}
$$

The time required from the beginning of the fermentation to the maximum rate of gas production, i.e. from time 0 to the inflection point (TIP), was calculated as proposed by Piva et al. (2002):

$$
\operatorname{TIP}(\mathrm{h})=\lambda+(\text { exponential phase } / 2)
$$

The parameters estimated by means of the Gompertz function and the $\mathrm{pH}$ values and the microbial metabolite concentrations in the fermentation fluid were analysed with the MIXED procedure of SAS (1998) by using residual maximum likelihood estimation and having the fixed effect of treatment and the random effect of fermentation series in the model. When the F-test was significant $(\mathrm{P}<0.05)$, differences between the treatments were identified by means of the Tukey test.

\section{Results}

The first step of fermentations with increasing formic acid concentrations $(2.9-17.7 \mathrm{mM})$ showed that the Gompertz bacterial growth model nicely fitted (mean $\mathrm{r}^{2}=0.997$ ) microbial growth recorded using the cumulative gas production technique (Table 2). Gas production started almost immediately, and the maximum rate of gas production $\left(\mu_{\mathrm{m}}\right)$ differed from that of the control treatment at the level of $20 \mu \mathrm{l}$ of formic acid per vessel, i.e. $11.8 \mathrm{mM}(\mathrm{P}<0.05)$. At this addition level, the maximum volume of gas produced $\left(\mathrm{V}_{\mathrm{F}}\right)$ was about $89 \%$ of the amount produced in the control vessels. The length of the exponential phase did not differ at different formic acid levels $(\mathrm{P}>0.05)$, but the time of the inflection point was earliest in vessels with the smallest formic acid addition $(\mathrm{P}<$ $0.05)$. Formic acid additions lowered the initial $\mathrm{pH}$ compared to the control treatment $(\mathrm{P}<0.05)$. At the initial $\mathrm{pH}$, the proportion of undissociated formic acid ranged from 2.2 to $5.0 \%$ with formic acid additions of 2.9 to $17.7 \mathrm{mM}$. At time zero, the fermentation fluid contained $62 \mathrm{mM}$ lactic acid and $7.2 \mathrm{mM}$ ammonia. After the 24-h fermentation, ammonia and lactic acid concentrations increased ca 2.6- and 2-fold compared to time zero, but they did not differ at different formic acid levels $(\mathrm{P}>$ $0.05)$.

Because different acidifiers were compared on a volume/weight basis rather than a molar ba-

Table 2. The effect of increasing formic acid additions $(0,5,10,20$, or $30 \mu \mathrm{l}$ per $45 \mathrm{ml})$ on the $\mathrm{pH}$ of the fermentation fluid $(0$ and $24 \mathrm{~h})$, estimated parameters for the Gompertz bacterial growth model applied to the gas production data, and ammonia and lactic acid concentrations in the fermentation fluid after 24-h incubation (least-square means, $\mathrm{n}=2$ ).

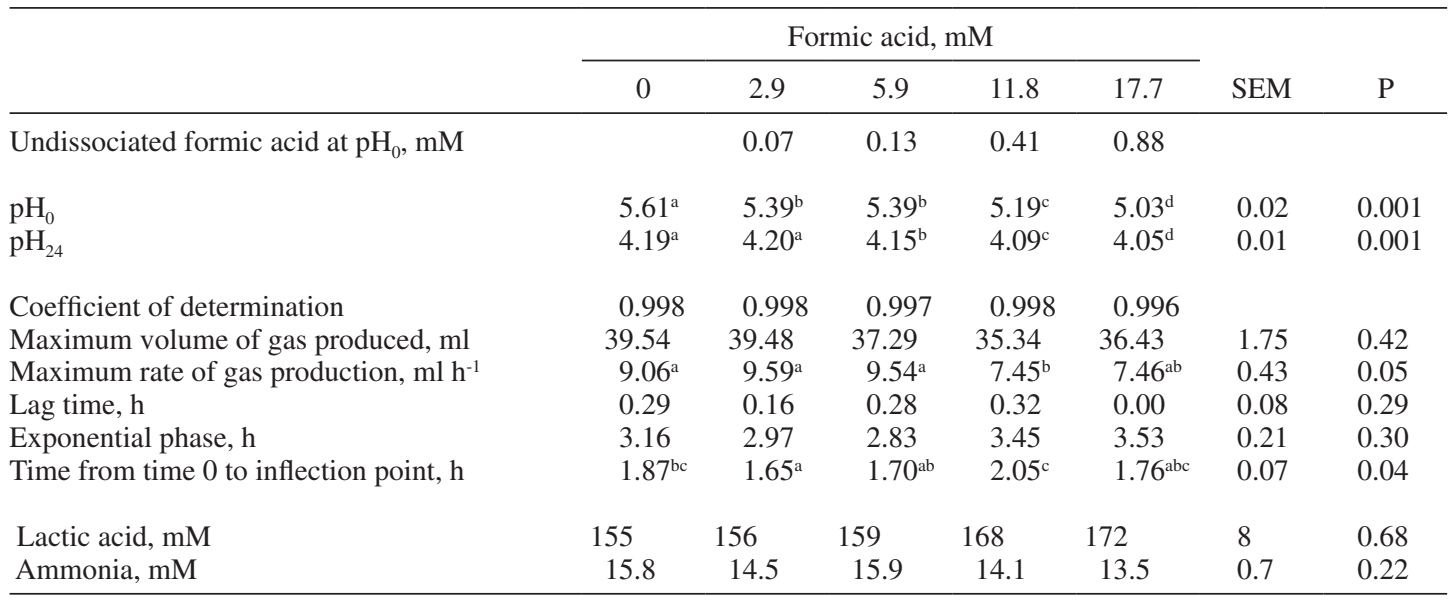

a,b,c,d Within a row, means with different superscripts are significantly different according to the Tukey test $(\mathrm{P}<0.05)$. 
Partanen, K. \& Jalava, T. Effects of organic acids and salts on swine microbial fermentation

sis, molar concentrations of acid additions varied from $2.3 \mathrm{mM}$ for citric acid to $11.8 \mathrm{mM}$ for formic acid (Table 3). In all the vessels that contained acidifiers, the initial $\mathrm{pH}$ was lower than in the control treatment $(\mathrm{P}<0.05)$, whereas no significant differences in final $\mathrm{pH}$ were detected. The calculated proportions of undissociated acid in vessels with different acids and salts were as follows: formic acid $1.4 \%$, propionic acid $11.0 \%$, lactic acid $1.0 \%$, citric acid $0.2 \%$, fumaric acid $0.8 \%$, calcium formate $0.7 \%$, sodium benzoate $1.8 \%$, potassium sorbate $6.9 \%$, and phosphoric acid $0.03 \%$. Because the $\mathrm{pH}$ of the fermentation medium decreased during the fermentation, the concentrations of undissociated acids probably increased too. However, we do not know how fast the $\mathrm{pH}$ changed in the vessels. Based on the maximum rate of gas production, formic acid was the acidifier most effective in restricting microbial fermentation in the vessels. In fact, it was the only acid that reduced the maximum rate of gas produced $\left(\mu_{\mathrm{m}}\right)$ compared to the control treatment $(\mathrm{P}<0.05)$. Furthermore, $\mu_{\mathrm{m}}$ was slower in vessels with formic acid than in vessels with calcium formate, citric acid, and potassium sorbate $(\mathrm{P}<0.05)$. Calcium formate addition increased $\mu_{\mathrm{m}}$ compared to the control treatment $(\mathrm{P}<0.05)$. The maximum volume of gas produced and the lag times did not differ between the treatments $(\mathrm{P}$ $>0.05)$. The length of the exponential phase ranged from 2.51 to $2.99 \mathrm{~h}$, and the time of the inflection point from 1.53 to $1.77 \mathrm{~h}$, but there were no significant differences between the acid treatments.

At time zero, the fermentation fluid contained $44 \mathrm{mM}$ lactic acid and $9.8 \mathrm{mM}$ ammonia. During the 24-h fermentation, lactic acid concentration increased 1.6- to 3.2-fold and ammonia concentrations about 1.5 -fold, but the differences between the acid treatments were not significant. Final ammonia concentrations were $16.0 \mathrm{mM}$ in the control treatment and $14.5-15.1 \mathrm{mM}$ in acid treatments, but differences were not significant. Final lactic acid concentration was $109 \mathrm{mM}$ in the control treatment, and it ranged from $71 \mathrm{mM}$ (calcium formate) to $139 \mathrm{mM}$ (formic acid) in acid treatments. However, because of large varia- tion, the F-test for the treatment effect was not significant. Volatile fatty acids were analysed only in the following selected treatments: control, formic acid, lactic acid, sodium benzoate, and potassium sorbate (Table 4). At time zero, the fermentation fluid contained $12.0 \mathrm{mM}$ acetic acid, $2.7 \mathrm{mM}$ propionic acid, and $0.07 \mathrm{mM}$-butyric acid. Formic acid, potassium sorbate, and sodium benzoate reduced total VFA, acetic acid, and propionic acid concentrations compared to the control treatment $(\mathrm{P}<0.05)$. Furthermore, lactic acid addition resulted in larger total VFA, acetic acid, and propionic acid concentrations than formic acid or sodium benzoate did $(\mathrm{P}<0.05)$. In addition, the molar proportion of acetic acid was increased by formic acid and sodium benzoate additions compared with the control treatment $(\mathrm{P}<$ $0.05)$. The concentrations and molar proportions of other VFA were not influenced by these acidifiers $(\mathrm{P}>0.05)$.

The mixing of small amounts $(1,3$, or $5 \%)$ of sodium benzoate or potassium sorbate with formic acid did not result in significant changes in gas production parameters compared to the results with plain formic acid (Table 5). At time zero, the fermentation fluid contained $44.0 \mathrm{mM}$ lactic acid, $9.8 \mathrm{mM}$ ammonia, $12.4 \mathrm{mM}$ acetic acid, $2.7 \mathrm{mM}$ propionic acid, and $0.07 \mathrm{mM}$ butyric acid. Lactic acid and ammonia concentrations did not differ between the acid treatments (P $>0.05)$. Compared to the control treatment, the concentrations of acetic and $n$-butyric acids were reduced by all formic-acid-based mixtures $(\mathrm{P}<$ $0.05)$ but not by plain formic acid $(\mathrm{P}>0.05)$. The results of the formic-acid-based mixtures did not differ from those of plain formic acid, with the exception of the acetic acid concentration in a mixture with $1 \%$ sodium benzoate $(\mathrm{P}<0.05)$ and the $n$-butyric acid concentration in a mixture with $3 \%$ sodium benzoate $(\mathrm{P}<0.05)$. The molar proportion of acetic acid was increased and that of propionic acid was decreased by all acid treatments $(\mathrm{P}<0.05)$, but only the mixture with $3 \%$ sodium benzoate resulted in a larger proportion of acetic acid than that due to plain formic acid ( $\mathrm{P}$ $<0.05)$. 
Vol. 14 (2005): 311-324.
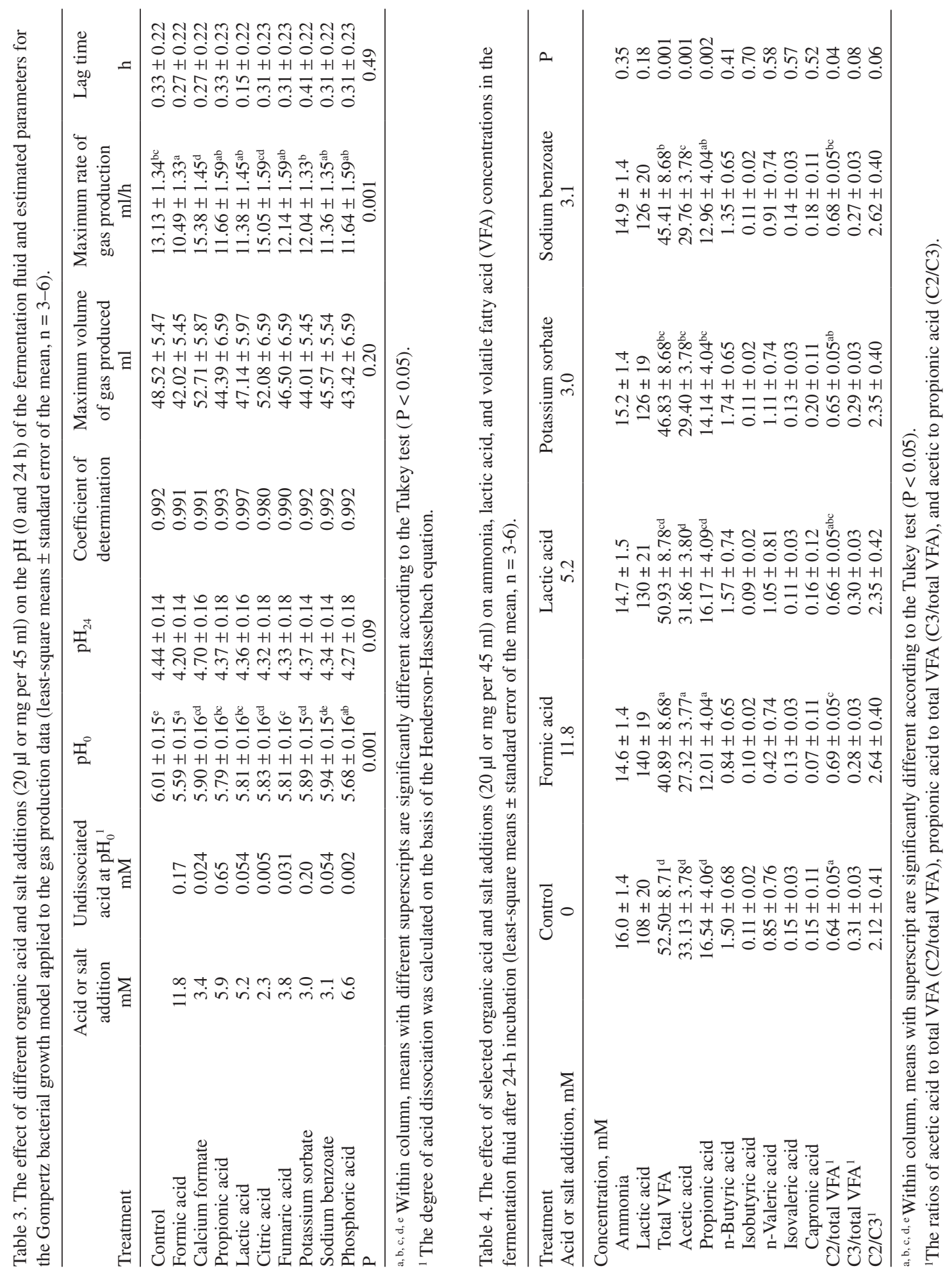
Partanen, K. \& Jalava, T. Effects of organic acids and salts on swine microbial fermentation

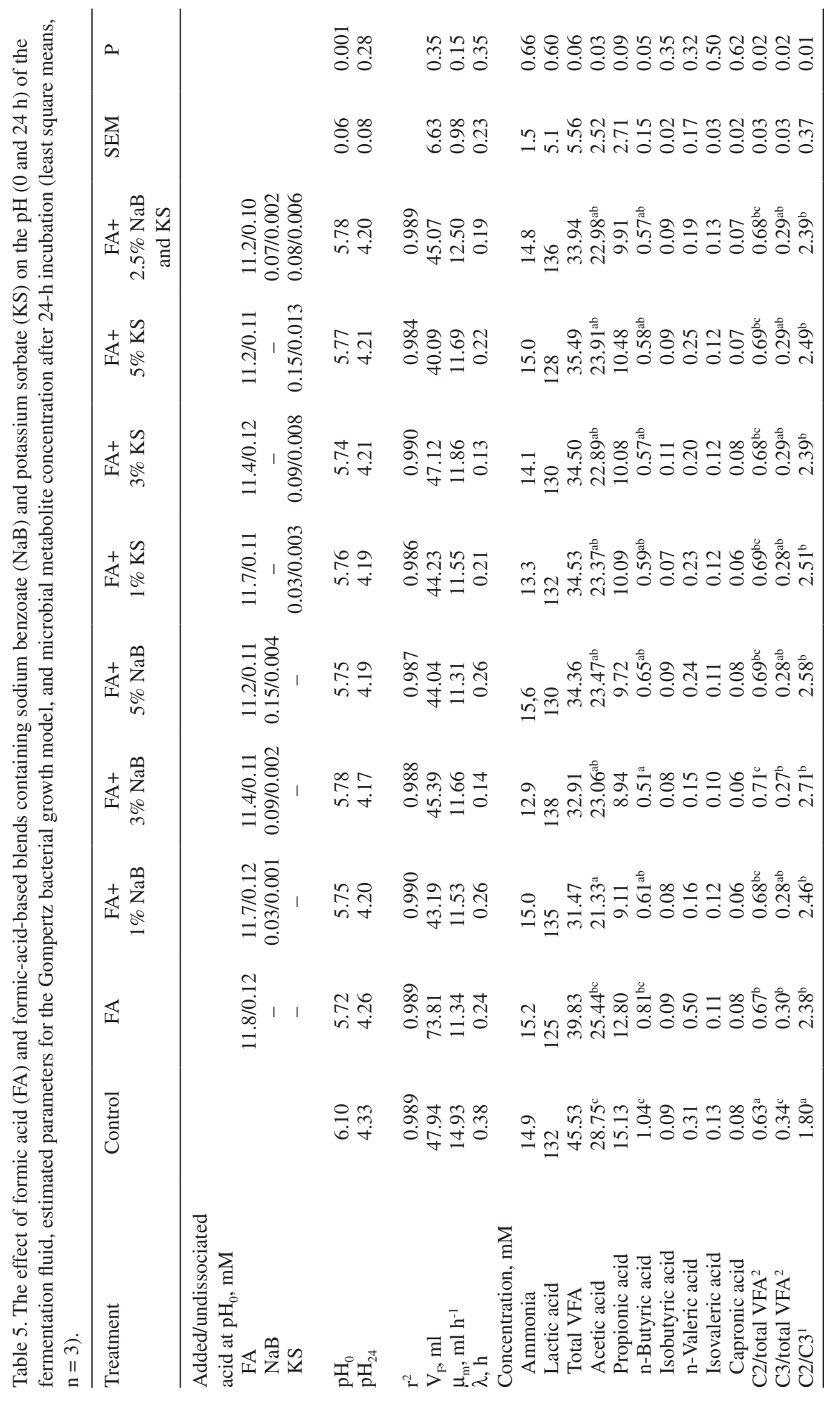


Vol. 14 (2005): 311-324.

\section{Discussion}

Organic acids are weak acids and therefore do not readily donate protons in aqueous solution. The relative strength of an acid is reflected in its dissociation constant $\mathrm{K}_{\mathrm{a}}$ or its $\mathrm{pK}_{\mathrm{a}}$ value $\left(-\log \mathrm{K}_{\mathrm{a}}\right)$. In water, weak acids dissociate to a certain degree into protons and anions, and the dissociation is $\mathrm{pH}$-dependent. Undissociated organic acids are lipid soluble and can freely diffuse across the bacterial membrane into the cytoplasm, causing acidification of the cytoplasm. This influences microbial metabolism because the action of certain enzymes is inhibited, bacterial cells are forced to use energy to remove protons instead of taking up nutrients, and acid anions are accumulated in the cell (Cherrington et al. 1991, Russell and Diez-Gonzalez 1998). In addition to being inhibitory agents, organic acids can act as a carbon and energy source for micro-organisms. This however depends on the concentration of the acid, its ability to enter the cell, and the capacity of the organism to metabolize the acid (Cherrington et al. 1991). Organic salts have antimicrobial effects too. Calcium formate, sodium benzoate, and potassium sorbate are well soluble in water (Chipley 1993, Sofos and Busta 1993), and we therefore assume that they completely dissolved in the culture medium. In aqueous solutions, organic salts ionize easily, and the resulting formate, benzoate and sorbate anions can react with water to produce formic, benzoic, and sorbic acid, respectively, depending on the $\mathrm{pH}$ of the milieu and the pKa value of the acid.

An in vitro gas production technique was used to investigate the ability of different organic acids (formic, propionic, lactic, citric, and fumaric acid), organic salts (calcium formate, potassium sorbate, and sodium benzoate), and inorganic phosphoric acid to modulate microbial fermentation in the digestive tract of piglets. Piva et al. (1999, 2002) used the gas production technique to study the effects of organic acids on caecal fermentation. Initially, our gas production system was set up by using fresh ileal digesta from a growing pig. However, the rate of fermentation varied greatly between different fermentation series, probably be- cause of large variation in the composition and microbial activity of digesta collected on different days. It was therefore difficult to adjust the acid concentration in the vessels to a level at which it would influence fermentation but not completely inhibit it. To provide a more consistent culture medium and to ensure inoculum rich in organisms, we pooled digesta from several collection days and stored it in frozen form. Because freezing stops microbial acitivity in digesta, fermentation medium was inoculated with fresh faeces from suckling piglets that were consuming creep feed. A similar approach using frozen gastric and ileal digesta inoculated with piglet faeces in an in vitro fermentation system has been used by Knarreborg et al. (2002). We chose to use piglet faeces as inoculum because dietary organic acid additions are primarily targeted towards piglets and because in piglets faeces are good indicators of general microbiological changes occurring in the gastrointestinal tract (Canibe et al. 2001).

The idea of in vitro gas production technique is to stimulate microbial fermentation occurring in the living digestive tract. However, there are several reasons which limit the direct application of these in vitro results to in vivo. The composition of ileal digesta from growing pig, which together with added feed served as substrate in the fermentation, differs from that of ileal digesta or faeces of young piglets (e.g. differences in diet composition, digestive capacity, and microflora). The initial $\mathrm{pH}$ was not adjusted to the same level, and it differed somewhat with different acid and salt additions. In vivo studies have shown that dietary organic acids may lower $\mathrm{pH}$ of gastric and duodenal contents but not further down in the gastrointestinal tract (Partanen and Mroz 1999, Mroz et al. 2001, Canibe et al. 2005). In the digestive tract of pig, both dietary organic acids as well as lactic acid and volatile fatty acids that are formed as a result of microbial fermentation are quickly absorbed and/or metabolized by intestinal microbes. Therefore, stomach and duodenum are considered as the primary sites of action of dietary organic acids (Partanen and Mroz 1999). Compared to in vivo, an in vitro batch fermentation system lacks the absorption and endproducts of microbial fermentation accumulate in 
the fermentation medium (Williams et al. 2005). Because no buffer was added to vessels during the 24-h incubation, the accumulation of microbial metabolites resulted in $\mathrm{pH}$ to decrease to al level which is lower than that generally found in the small and large intestinal contents of piglets (Canibe et al. 2001). The production of gas and microbial metabolites is dependent on the microbial population and available substrate in the fermentation medium. Heterofermentative lactic acid bacteria produce lactic acid and large amounts of carbon dioxide, whereas heterofermentative lactic acid bacteria produce primarily lactic acid but no gas. Short chain fatty acids, gaseous hydrogen and carbon dioxide are the primary products of hind gut fermentation (Ewing and Cole 1994). Gas is also released from buffer when it reacts with short chain fatty acids (Williams et al. 2005). Despite of these shortcomings, the in vitro gas production technique is a useful tool for primary screening of feed components (Williams et al. 2005) or dietary acidifiers (Piva et al. 1999) to find potential candidates for in vivo studies.

Formic acid had the greatest effect on the maximum rate of gas production, thereby exhibiting a greater inhibiting effect on microbial fermentation than the other acidifiers. Calcium formate differed from other acidifiers in that it stimulated microbial fermentation compared to the control treatment, as indicated by a higher maximum rate of gas production than in the control treatment. The effects of other acids did not differ from the control treatment. Piva et al. (1999) used the gas production technique and caecal digesta to evaluate the effects of different organic acids. They reported that 120 $240 \mathrm{mM}$ formic and propionic acid decreased the maximum volume of gas produced by $29-55 \%$ 24-48\% respectively, whereas acetic acid had no effect, and lactic acid increased gas production by $59-24 \%$. The maximum rate of gas produced was slowed down by formic, acetic, and propionic acids and increased by lactic acid. In the in vitro study by Knarreborg et al. (2002), benzoic acid was the most effective in inhibiting the growth of coliform bacteria in the stomach contents ( $\mathrm{pH} 4.5$ ), followed by fumaric, lactic, butyric, formic, and propionic acid, when the acids were used at a con- centration of $100 \mathrm{mM}$. In small intestinal contents ( $\mathrm{pH}$ 5.5), the order of the effectiveness of the acids $(100 \mathrm{mM})$ was somewhat different: benzoic acid > formic acid $>$ butyric acid $>$ propionic acid $>$ lactic acid $>$ fumaric acid. Lactic acid bacteria were able to grow in the presence of several acids both in the stomach and small intestinal contents, but their growth rates were reduced. Only fumaric acid and sodium benzoate exhibited strong antimicrobial properties towards lactic acid bacteria.

The gastrointestinal tract of pigs hosts a diverse and dynamic community of bacteria, which responds to dietary changes and infections (Leser et al. 2001). Yeasts are also found in the gastrointestinal tract of pigs (Canibe et al. 2001). It is reasonable to assume that the effects of different acidifiers on intestinal microflora differ. Formic acid is a strong acidulant that exhibits antimicrobial activity primarily against yeast and some bacteria such as Escherichia coli (Lueck 1980). Reduced lactic acid bacteria counts and/or lactic acid concentrations have been reported in the stomach and/or small intestine of pigs fed formic acid supplemented diets (Roth et al. 1992, Partanen et al. 2001a, Canibe et al. 2005). In the present study, the vessels with formic acid resulted in the highest concentration of lactic acid after $24 \mathrm{~h}$ of fermentation. Lactic acid bacteria are able to grow at a low $\mathrm{pH}$, and differences in initial $\mathrm{pH}$ may have influenced the fermentation pattern in the vessels. Final lactic acid concentration was negatively correlated with both initial $(\mathrm{r}=-0.61, \mathrm{P}<0.001)$ and final $\mathrm{pH}(\mathrm{r}=$ $-0.93, \mathrm{P}<0.001)$. Propionic acid is primarily effective against moulds, but its activity against bacteria is poor, and some yeast can metabolize it (Foeding and Busta 1991). Lactic acid is produced in the stomach and small intestine of pigs by several bacterial species, e.g. Lactobacillus, Bifidobacterium, and Streptococcus. The antimicrobial activity of lactic acid is directed primarily against bacteria, whereas many yeast can metabolize it (Foeding and Busta 1991). Citric acid is generally a less effective antimicrobial agent because many micro-organisms can metabolize it (Foeding and Busta 1991). In this study, calcium formate stimulated microbial fermentation in the small intestine. Piva et al. (2002) reported an increased rate of gas 
Vol. 14 (2005): 311-324.

production when they used an acid mixture containing citric, malic, fumaric, and phosphoric acids. Increased lactic acid production has been reported in the ileal contents of pigs fed diets supplemented with citric acid (Fasshauer and Kienzle 1995). Calcium formate contains ca $33 \%$ calcium (20 mg addition provided $6.6 \mathrm{mg}$ calcium per 45 $\mathrm{ml}$ fermentation fluid), which may have acted as a buffer and higher $\mathrm{pH}$ has stimulated microbial fermentation. The lowest concentration of lactic acid observed in the calcium formate treatment indicates that a higher $\mathrm{pH}$ was not favourable for lactic acid producing bacteria.

The growth-promoting effect of dietary organic acids has been explained in part by decreased proteolysis and the decreased release of toxic substances such as ammonia and amines (Kirchgessner and Roth 1988). Although, compared to the control treatment, all organic acid additions resulted in numerically 6-10\% lower concentrations of ammonia in the fermentation fluid after 24-h incubation, the differences between the results die to the different acids were not significant. The number of vessels would have had to be greater to be able show any possible significant effects. Piva et al. (2002) reported that an organic acid mixture containing phosphoric, citric, fumaric, and malic acid reduced ammonia concentration by about $13 \%$ in the caecal fermentation fluid. Organic acid also reduced total VFA production and the ratio of acetic to propionic acid. In our study, VFA were determined only in the control, formic acid, lactic acid, potassium sorbate and sodium benzoate treatments. Of these, formic acid addition resulted in the largest reduction in total VFA, acetic acid, and propionic acid concentrations. The effects of sodium benzoate and potassium sorbate were intermediate between those of lactic and formic acids. Formic acid and potassium diformate additions have been shown to reduce ammonia and lactic acid concentrations in the stomach and small intestinal contents in vivo (Roth et al. 1992, Canibe et al. 2001, Partanen et al. 2001a). In vivo, dietary formic acid has been shown to increase total VFA and acetic acid concentrations in the small intestinal contents (Partanen et al. 2001a). The discrepancy between the in vitro and in vivo results could be due to the fact that lactic acid is quickly absorbed and/or metabolized by microflora in the digestive tract of pigs.

The second objective of this study was to investigate the effects of adding small amounts of sodium benzoate and potassium sorbate to formic acid. We found that the addition of 5\% potassium sorbate to formic acid was the most effective in reducing the maximum volume of gas produced ( $\mathrm{V}_{\mathrm{F}}$ was $78 \%$ of the control treatment). The pKa value of sorbic acid is 4.76 . The primary inhibitory activity of sorbic acid is against yeasts and moulds; the activity against bacteria is not as comprehensive and appears to be selective (Sofos and Busta 1993). Benzoic acid exhibits antimicrobial activity against bacteria, yeast and moulds (Chipley 1993). Ileal pig digesta contains yeasts, and it has been shown that their numbers decrease as a result of dietary additions of potassium diformate, formic acid, and benzoic acid but increase due to lactic acid additions (Maribo et al. 2000a, b, Canibe et al. 2001). Bacteria species inhibited by sorbate include Escherichia, Lactobacillus, and others. The antimicrobial action of sorbate is $\mathrm{pH}$ dependent and increases when the $\mathrm{pH}$ approaches sorbate's $\mathrm{pKa}$ value (4.76). Although the activity of sorbates is greater at low $\mathrm{pH}$ values, sorbates have the advantage of being effective at $\mathrm{pH}$ values as high as 6.5-7.0. The maximum $\mathrm{pH}$ for most other common preservatives is lower (Sofos and Busta 1993). Mixtures with sodium benzoate or potassium sorbate resulted in changes in total VFA, acetic, propionic, and $n$-butyric acid production. In performance studies, dietary sorbic acid additions (1.2$2.4 \%$ ) have had profound growth-promoting effects (14-27\% increase in growth rate) in weaned piglets with a body weight between 7 and $26 \mathrm{~kg}$ (Kirchgessner et al. 1995). Maribo et al. (2000b) reported that 2.0 and $1.0 \%$ benzoic acid in starter and weaner diets enhanced the growth rate of piglets aged 4-6 and 6-10 weeks by 18 and $16 \%$, respectively. Jørgenssen and Boes found that an addition of $1.0 \%$ benzoic acid to diets increased the growth rate of piglets weighing $9-32 \mathrm{~kg}$ by ca $10 \%$.

In conclusion, this in vitro study shows that organic acids and salts used as growth promoters in 
pig diets differ in their ability to modulate microbial fermentation in the digestive tract of piglets. Formic acid was the acidifier most effective in restricting microbial fermentation in a culture medium that contained ileal digesta and feed as substrate and faecal inoculum from piglets. Use of mixtures of formic acid with a small amount of sorbate or benzoate changed fermentation profiles more than the use of plain formic acid. Use of mixtures of formic acid with potassium sorbate or sodium benzoate altered microbial metabolite concentrations more than use of plain formic acid. The effects of these mixtures should therefore be investigated further in future in vivo studies.

Acknowledgements. The authors would like to thank Kemira Chemicals/Formics for financing this study.

\section{References}

Breves, G., Dreyer, J. \& Oslage, H.J. 1991. In vitro-studies on microbial hindgut metabolism in pigs. Advances in Animal Physiology and Animal Nutrition 22: 89-92.

Canibe, N., Højberg, O., Højsgaard, S. \& Jensen, B.B. 2005. Feed physical form and formic acid addition to the feed affect the gastrointestinal ecology and growth performance of growing pigs. Journal of Animal Science 83: 1287-1302.

Canibe, N., Steien, S.H., Øverland, M. \& Jensen, B.B. 2001. Effect of K-diformate in starter diets on acidity, microbiota, and the amount of organic acids in the digestive tract of piglets, and on gastric alterations. Journal of Animal Science 79: 2123-2133.

Cherrington, C.A., Hinton, M., Mead, G.C. \& Chopra, I. 1991. Organic acids: chemistry, antibacterial activity and practical applications. Advances in Microbial Physiology 32: 87-108.

Chipley, J.R. 1993. Sodium benzoate and benzoic acid. In: Davidson, P.M. \& Branen, A.L. (eds.). Antimicrobials in foods. New York, USA: Marcel Dekker, Inc. p. 11-48.

Ewing, B. \& Cole, B. 1994. The living gut. An introduction to micro-organisms in nutrition. Context, Duncannon, Ireland. $220 \mathrm{p}$.

Fasshauer, U. \& Kienzle, E. 1995. Effect of citric acid, olaquindox, zinc-bacitracin and zinc oxide on precaecal digestion of crude nutrients and ileocaecal flow of minerals in minipigs. Journal of Animal Physiology and Animal Nutrition 74: 219-226.

Foeding, P.M. \& Busta, F.F. 1991. Chemical food preservatives. In: Block, S.S. (ed.). Disinfection, sterilization and preservation. Philadelphia, PA, USA: Lea \& Febiger, Philadelphia, PA. p. 802-832.
Haacker, K., Block, H.J. \& Weissbach, F. 1983. Zur kolorimetrischen Milchsäurebestimmung in Silagen mit p-Hydroxydiphenyl. Archive für Tierernährung 33: 505-512.

Huhtanen, P., Blauwiekel, R. \& Saastamoinen, I. 1998. Effects of intraruminal infusion of propionate and butyrate with two different protein supplements on milk production and blood metabolites in dairy cows receiving grass silage-based diet. Journal of the Science of Food and Agriculture 77: 213-222.

Jensen, B.B. 1998. The impact of feed additives on the microbial ecology of the gut in young pigs. Journal of Animal and Feed Sciences 7: 45-64.

Jørgensen, L. \& Boes, J. 2004. Benzoesyre og mælke-/myresyre til smågrise. Landsudvalget for Svin. Faglig Publikation, Meddelelse nr. 677. 10 p. Cited 28 February 2005. Updated 6 November 2004. Available on the Internet: http://www.lu.dk/index.aspx?id=45ae1f6f-14c348d4-8595-e0c7f4711343

Kirchgessner, M. \& Roth, F.X.1988. Ergotrope Effekte durch Organische Säuren in der Ferkelaufzucht und Schweinemast. Übersichten zur Tierernährung 16: 93-108.

Kirchgessner, M., Roth, F.X. \& Paulicks, B.R. 1995. Zur nutritiven Wirkung von Sorbinsäure in der Ferkelaufzucht. Journal of Animal Physiology and Animal nutrition 74: 235-242.

Knarreborg, A., Miquel, N., Granli, T. \& Jensen, B.B. 2002. Establishment and application of an in vitro methodology to study the effects of organic acids on coliform and lactic acid bacteria in the proximal part of the gastrointestinal tract of piglets. Animal Feed Science and Technology 99: 131-140.

Leser, T.D., Amenuvor, J.Z., Jensen, T.K., Lindecrona, R.H., Boye, M. \& Iler, K.M. 2001. Culture-independent analysis of gut bacteria: the pig gastrointestinal tract microbiota revisited. In: Proceedings workshop on alternatives to feed antibiotics and anticoccidials in the pig and poultry meat production. 4 p. Cited 28 February 2005, Updated 10 November 2004. Available in the Internet: http://www-afac.slu.se/Workshop\%20Norge/ foredragmanus\%20Leser.pdf

Lueck, E. 1980. Antimicrobial food additives: characteristics, uses, effects. In: Lueck, E. (ed.). Antimicrobial food additives. New York, USA: Springer-Verlag. p. 35-197.

McCullough, H. 1967. The determination of ammonia in whole blood by direct colorimetric method. Clinica Chimica Acta 17: 297-304.

Maribo, H., Jensen, B.B. \& Hedemann, M.S. 2000a. Forskellige doseringer af organicke syrer til smågrise. Landsudvalget for Svin. Faglig Publikation, Meddelelse nr. 469. 21 p. Cited 28 February 2005. Updated 6 April 2000. Available on the Internet: http://www.lu.dk/index. aspx?id=b6cc7878-901b-4384-b0b2-7b7fb7c00ab1

Maribo, H., Olsen, L.E., Jensen, B.B. \& Miquel, N. $2000 \mathrm{~b}$. Produkter til smågrise: kombinationen af mælkesyre og myresyre og benzoesyre. Landsudvalget for Svin. Faglig Publikation, Meddelelse nr. 490. 16 p. Cited 28 February 2005. Updated 23 November 2000. Available on the Internet: http://www.lu.dk/index.aspx?id= 47e22c9c-b401-4ce1-838e-115dd8d62700

Mroz, Z., Jongbloed, A.W., van der Weij-Jongbloed, R. \& Øverland, M. 2001. Postprandial flow rates of formic acid and potassium in duodenal digesta of weaned pig- 
Vol. 14 (2005): 311-324.

lets fed graded doses of potassium diformate. In: Lindeberg, J.E. \& Ogle, B. (eds.). Proceedings of the 8th Symposium on digestive physiology of pigs. Oxon, UK: CABI Publishing. p. 305-307.

Partanen, K., Jalava, T., Valaja, J., Perttilä, S., SiljanderRasi, H. \& Lindeberg, H. 2001a. Effect of dietary carbadox or formic acid and fibre level on ileal and faecal nutrient digestibility and microbial metabolite concentrations in ileal digesta of the pig. Animal Feed Science and Technology 93: 137-155.

Partanen, K. \& Mroz, Z. 1999. Organic acids for performance enhancement in pig diets. Nutrition Research Reviews 12: 117-145.

Partanen, K., Valaja, J., Jalava, T. \& Siljander-Rasi, H. 2001b. Composition, ileal amino acid digestibility and nutritive value of organically grown legume seeds and conventional rapeseed cakes for pigs. Agricultural and Food Science in Finland 10: 309-322.

Piva, A., Biagi, G., Meola, E., Luchansky, J.B. \& Gatta, P.P. 1999. Inhibitory/stimulatory effect of organic acids on intestinal microflora. Journal of Animal Science 77: 199. (abstract)

Piva, A., Casadei, G. \& Biagi, G. 2002. An organic acid blend can modulate swine intestinal fermentation and reduce microbial proteolysis. Canadian Journal of Animal Science 82: 527-532.

Roth, F.X., Eckel, B., Kirchgessner, M. \& Eidelsburger, U. 1992. Zum Einfluss von Ameisensäure auf pH-Wert, Trockenmassegehalt, Konzentrationen an flüchtigen Fettsäuren und Milchsäure im Gastrointestinaltrakt. 3. Mitteilung. Untersuchungen zur nutritiven Wirksamkeit von organischen Säuren in der Ferkelaufzucht. Journal of Animal Physiology and Animal Nutrition 67: 148156.

Russell, J.B. \& Diez-Gonzalez, F. 1998. The effects of fermentation acids on bacterial growth. Advances in Microbial Physiology 39: 205-234.

SAS 1998. SAS/STAT User's Guide (Release 6.03). Cary, NC, USA: SAS Institute, Inc.

Schofield, P., Pitt, R.E. \& Pell, A.N. 1994. Kinetics of fiber digestion from in vitro gas production. Journal of Animal Science 72: 2980-2991.

Sofos, J.N. \& Busta, F.F. 1993. Sorbic acid and sorbates. In: Davidson, P.M. \& Branen, A.L. (eds.). Antimicrobials in foods. New York, USA: Marcel Dekker, Inc. p. 49-94.

van Leeuwen, P., van Kleef, D.J., van Kempen, G.J.M., Huisman, J. \& Verstegen, M.W.A. 1991. The post-valve Tcaecum cannulation technique in pigs applicated to determine the digestibility of amino acid in maize, groundnut and sunflower meal. Journal of Animal Physiology and Animal Nutrition 65: 183-193.

Williams, B.A., Bosch, M.W., Boer, H., Verstegen, M.W.A. \& Tamminga, S. 2005. An in vitro batch culture method to assess potential fermentability of feed ingredients for monogastric diets. Animal Feed Science and Technology 123-124: 445-462.

Zwietering, M.H., Jongenburger, I., Rombouts, F.M. \& van't Riet, K. 1990. Modeling of the bacterial growth curve. Applied and Environmental Microbiology 56: 18751881.

Zwietering, M.H., Rombouts, F.M. \& van't Riet, K. 1992. Comparison of definitions of the lag phase and the exponential phase in bacterial growth. Journal of Applied Bacteriology 72: 139-145. 
Partanen, K. \& Jalava, T. Effects of organic acids and salts on swine microbial fermentation

\title{
SELOSTUS
}

\section{Orgaanisten happojen ja suolojen vaikutus mikrobifermentaatioon porsaan ruuansulatuskanavassa in vitro}

\author{
Kirsi Partanen ja Taina Jalava \\ MTT (Maa- ja elintarviketalouden tutkimuskeskus)
}

\begin{abstract}
In vitro -kaasuntuotantomenetelmällä selvitettiin erilaisten orgaanisten happojen (muurahais-, propioni-. maito-, sitruuna- ja fumaarihappo) ja suolojen (kalsiumformiaatti, kaliumsorbaatti ja natriumbentsoaatti) sekä epäorgaanisen fosforihapon mahdollisuutta muokata mikrobifermentaatiota porsaan ruoansulatuskanavassa. Lasipulloihin laitettiin inkubaatiota varten $40 \mathrm{ml}$ seosta, jossa oli $53 \%$ puskuria, $45 \%$ ohutsuolen ruokasulaa ja $2 \%$ sontaa, sekä $5 \mathrm{ml}$ puskuria, $0,5 \mathrm{~g}$ rehua ja $20 \mu \mathrm{l}$ nestemäisiä tai $20 \mathrm{mg}$ kiinteitä happoja ja suoloja. Kaasuntuotanto mitattiin automaattisesti 15 minuutin välein seuraavan $24 \mathrm{~h}$ ajan. Muurahaishappo oli ainoa, joka hidasti maksimaalista kaasun muodostumisnopeutta kontrolliin verrattua. Muurahaishappoa sisältäneissä pulloissa kaasua muodostui hitaammin kuin kalsiumformiaattia, sitruunahappoa ja kaliumsorbaattia sisältäneissä pul-
\end{abstract}

loissa. Kalsiumformiaatti nopeutti kaasun muodostumista kontrolliin verrattuna. Muodostuneen kaasun kokonaismäärässä ei ollut merkitseviä eroja happojen ja suolojen välillä. Kun tutkimme muurahaishappopohjaisia seoksia, joissa oli 1-5\% natriumbentsoaattia ja/tai kaliumsorbaatia, kaasun muodostumista kuvaavat parametrit eivät eronneet puhtaan muurahaishapon vaikutuksesta. Kaikki muurahaishappopohjaiset seokset pienensivät haihtuvien rasvahappojen, etikkahapon, propionihapon ja n-voihapon pitoisuutta fermentaationesteessä, mutta ei pelkkä muurahaishappo. Johtopäätöksenä on, että orgaanisilla hapoilla ja niiden suoloilla on erilainen kyky muokata mikrobifermentaatiota porsaan ruuansulatuskanavassa. Lisäämällä natriumbentsoaattia tai kaliumsorbaattia muurahaishappoon voidaan muuttaa fermentaation tyyppiä. 